

Originally published as:

Goderis, S., Tagle, R., Schmitt, R. T., Erzinger, J., Claeys, Ph. (2007):

Platinum group elements provide no indication of a meteoritic component in ICDP cores from the Bosumtwi crater, Ghana. - Meteoritics and Planetary Science, 42, 4-5, 731-741. 


\title{
Platinum group elements provide no indication of a meteoritic component in ICDP cores from the Bosumtwi crater, Ghana
}

\author{
S. GODERIS ${ }^{1,2}$, R. TAGLE ${ }^{1}$, R. T. SCHMITT ${ }^{3}$, J. ERZINGER $^{4}$, and Ph. CLAEYS ${ }^{1 *}$ \\ ${ }^{1}$ Department of Geology, Vrije Universiteit Brussel, Pleinlaan 2, B-1050 Brussels, Belgium \\ ${ }^{2}$ Department of Geology and Soil Science, Ghent University, Krijgslaan 281, 9000 Ghent, Belgium \\ ${ }^{3}$ Department of Mineralogy, Natural History Museum, Berlin, 10099 Berlin, Germany \\ ${ }^{4}$ GeoForschungsZentrum Potsdam, 14473 Potsdam, Germany \\ *Corresponding author. E-mail: phclaeys@vub.ac.be
}

(Received 09 August 2006; revision accepted 21 December 2006)

\begin{abstract}
In an attempt to identify the type of projectile, 14 samples from the Bosumtwi crater in Ghana were analyzed for platinum group element (PGE) concentrations by nickel sulfide fire assay inductively coupled plasma-mass spectrometry (ICP-MS). The majority of the samples come from the impactite material recovered by cores LB-07A and LB-08A, which were drilled by the International Continental Scientific Drilling program (ICDP). One sample originates from the fallback material found at the contact between the impactite and the overlying lake sediment in core LB-05B. No clear signature of a meteoritic contamination was identified in the 13 impactite samples. The target rock apparently dominates the PGE contribution in the impactites. These results agree with the PGE concentrations reported for the suevites collected at the crater rim and in other parts of the Bosumtwi ICDP cores. However, based on $\mathrm{Cr}$ and Os isotopic signatures, a meteoritic component could be present in the sample of fallback material, supporting the reports of the existence of meteoritic material in the Ivory Coast tektites. Further analyses of the fallback material from the Bosumtwi drill cores should confirm (or not) this first result.
\end{abstract}

\section{INTRODUCTION}

The Bosumtwi impact crater has a diameter of $10.5 \mathrm{~km}$ and is located near the town of Kumasi, in Ghana, West Africa $\left(6^{\circ} 30^{\prime} \mathrm{N}, 1^{\circ} 25^{\prime} \mathrm{W}\right)$. With an age of $\sim 1.07 \mathrm{Myr}$, it is one of youngest, best-preserved, and most easily accessible mediumsized craters on Earth. The closed basin of Lake Bosumtwi, the current diameter of which is roughly $8.5 \mathrm{~km}$, occupies the center of the crater. The crater rim is clearly visible, and the structure forms a marked depression in the forested regional landscape. In terms of crater morphology, its diameter places Bosumtwi at the transition between a central peak and a peakring structure. Detailed studies of craters in this size range are important for understanding crater-formation processes on Earth and other rocky planets. The target lithologies are essentially composed of Proterozoic (2.1-2.2 Gyr) units of the Birimian Supergroup that consists of lower greenschist facies metasediments, schists, phyllites, graywackes, quartzite, and a minor granitic component. Along with the Ries and Chesapeake Bay craters, Bosumtwi is one of the rare craters to have produced a tektite strewn field. It is considered the probable source of the Ivory Coast tektites and microtektites recovered in neighboring Ivory Coast and from deep-sea drillings in the east tropical Atlantic, respectively (Koeberl et al. 1998).

In the summer and fall of 2004, the International Continental Scientific Drilling Project (ICDP) carried out a large-scale drilling campaign in the Bosumtwi crater (Koeberl et al. 2007a). Detailed geophysical studies paved the way for the drillings (Plado et al. 2000; Karp et al. 2002; Scholtz et al. 2002; Pesonen et al. 2003). Several cores (16) were drilled in the lake sediments to extract paleolimnological and paleoclimatic data to document the environmental changes taking place over the last million years in this key region affected by West African monsoon. Two cored holes (LB-07A and LB-08A) located in the crater center penetrated through the lake sediments to sample the impactite lithologies (Koeberl et al. 2007a; Koeberl et al. 2007b). These boreholes were located on high-quality seismic lines and reached total depths of $540 \mathrm{~m}$ for LB-07A and $450 \mathrm{~m}$ for LB-08A. Based on the seismic profile, LB-07A was drilled in the depression or trough at the base of the central peak and LB-08A on the flank of the central peak. Both cores recovered melt and polymict/monomict breccias and both bottomed in fractured 

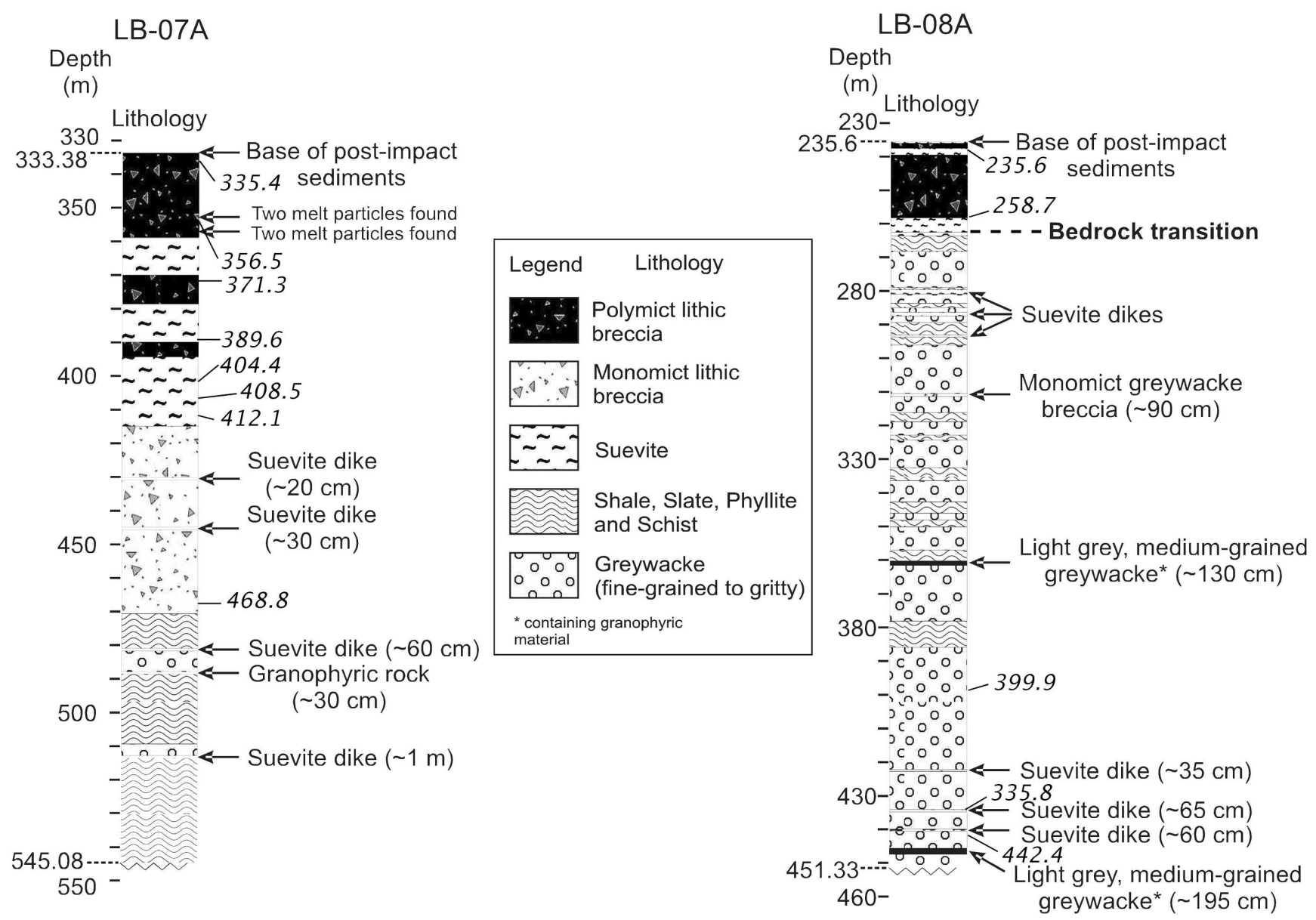

Fig. 1. The location of the samples analyzed in this study reported on the generalized log of the Bosumtwi cores LB-07A and LB-08A (Koeberl et al. 2006; Koeberl et al. 2007a).

bedrock. The impactite cores were shipped to the GeoForschungsZentrum Potsdam (GFZ), Germany, to be described and scanned. In January 2005, the $\sim 350 \mathrm{~m}$ of impactites recovered were sampled by the participants of the ICDP project. A reference lithological log (Fig. 1) of these two cores has been established by Koeberl et al. (2007a, 2007b). The petrography and shock characteristics of the impactites are described in detail in accompanying papers (Deutsch et al. 2007; Ferrière et al. 2007a, 2007b; Karikari et al. 2007; Morrow 2007).

During the crater-forming process, a small fraction of meteoritic material is incorporated as vapor and/or melt into a much larger volume of impactite derived from the molten or shocked target lithologies. The detection of traces of meteoritic material in terrestrial crater rocks confirms the impact origin of the structure and in some cases provides information on the nature of the projectile. Several approaches can be used. Siderophile elements in general, and the platinum group elements (PGE) in particular, are significantly enriched in meteorites compared to the Earth's crust. Their elevated concentrations reveal the presence of a meteoritic component in crater lithologies (Palme 1982;
Koeberl 1998), while their specific interelemental ratios can be used to characterize the projectile (McDonald et al. 2001; Tagle and Hecht 2006). Meteorites and the terrestrial crust also differ significantly in some of their isotopic signatures. The Re-Os system, which is based on the decay of ${ }^{187} \mathrm{Re}$ to ${ }^{187} \mathrm{Os}$, is thus far the most sensitive for detecting even limited contaminations by a meteoritic component (Koeberl and Shirey 1997; Koeberl 1998; Koeberl et al. 2002). Most meteorites contain elevated Os and low Re concentrations relative to terrestrial material and have ${ }^{187} \mathrm{Os} /{ }^{188} \mathrm{Os}$ ratios significantly lower $(\sim 0.11$ to 0.18$)$ than those $(\sim 1$ to 1.2$)$ measured in the Earth's crust (Koeberl 1998; Koeberl et al. 2002). Consequently, even light contamination by meteoritic material strongly affects the Os isotopic signature of the crater impactite. Although less sensitive and requiring a major contribution of extraterrestrial $\mathrm{Cr}$ because of the relatively elevated background concentration of $\mathrm{Cr}$ in some terrestrial rocks, the ${ }^{53} \mathrm{Cr} /{ }^{52} \mathrm{Cr}$ ratio discriminates efficiently between different projectiles (Shukolyukov and Lugmair 1998; Shukolyukov et al. 1999; Koeberl et al. 2002). The ${ }^{53} \mathrm{Cr} /{ }^{52} \mathrm{Cr}$ value is expressed in $\varepsilon$-units, or 1 part per $10^{4}$, or $0.1 \%$. In the early solar system, ${ }^{53} \mathrm{Mn}$, which decays in $\sim 3.7 \mathrm{Myr}$ to ${ }^{53} \mathrm{Cr}$, 
was heterogeneously distributed and/or $\mathrm{Mn} / \mathrm{Cr}$ fractionation took place. The meteorite families thus show different excesses of ${ }^{53} \mathrm{Cr}$ compared to the terrestrial value, which by definition is set to zero. It is clear that each method has its advantages and limitations and that combining them provides optimal results. Comparative reviews of the procedures and techniques have been recently published (Koeberl 1998; Koeberl et al. 2002; McDonald et al. 2001; McDonald 2002; Tagle and Claeys 2005; Tagle and Hecht 2006).

The goal of this study is to use PGE measured on core samples to try to identify and characterize the type of projectile responsible for the formation of the Bosumtwi crater. Comparisons of the elemental ratios of the different PGE measured in impactites, with similar ratios determined on various types of meteorites, makes it possible to obtain a refined projectile identification (McDonald et al. 2001; McDonald 2002; Tagle and Claeys 2005; Tagle and Hecht 2006). This comparative approach relies on an extensive database of the PGE composition of different types of meteorites. In some cases when using this database, it becomes possible to advocate a specific type of chondrite as potential projectile. The methodology used here has been described in detail by Tagle and Claeys (2005) and more recently reviewed by Tagle and Hecht (2006).

\section{METEORITIC COMPONENT IN THE IVORY COAST TEKTITES AND BOSUMTWI LITHOLOGIES}

Palme et al. (1978) were the first authors to report the presence of small positive Ir and Os anomalies in the Ivory Coast tektites (in the order of $0.3-0.4 \mathrm{ng} / \mathrm{g}$ ). Their nonchondritic ratio led these authors to favor an ironmeteorite projectile. Jones (1985) preferred a terrestrial origin, related to the abundant gold mineralizations known in the region, for the elevated PGE concentrations found in the tektites. The concentrations and isotopic ratios of Os and Re in Ivory Coast tektites as well as impact glasses and different target rocks from the Bosumtwi region were measured using negative thermal ionization mass spectrometry (Koeberl and Shirey 1993). These analyses confirmed the elevated Os concentrations in both tektites and target lithologies (up to $\sim 0.3 \mathrm{ng} / \mathrm{g}$ ). The Ivory Coast tektites yielded ${ }^{187} \mathrm{Os} /{ }^{188} \mathrm{Os}$ ratios of around 0.155 to 0.213 compared to the typical crustal values of 1.52 to 5.01 measured in the Bosumtwi target rocks. The lower ${ }^{187} \mathrm{Os} /{ }^{188} \mathrm{Os}$ signature of the tektites clearly supports the presence of a small $(0.1$ to $0.6 \mathrm{wt} \%)$ meteoritic component (Koeberl and Shirey 1993); however, it does not characterize the type of projectile. Recently, Koeberl et al. (2004) measured the $\mathrm{Cr}$ isotope composition of a sample of Ivory Coast tektite, and obtained a positive ${ }^{53} \mathrm{Cr} /{ }^{52} \mathrm{Cr}$ value of $0.30 \pm 0.06 \varepsilon$ (with an uncertainty of $2 \sigma_{\text {mean }}$ ) compared to the standard terrestrial value considered to be zero. This positive value excludes a carbonaceous projectile, and is higher than that commonly determined for enstatite chondrites $(0.17 \pm$
$0.06 \varepsilon$ ), so these authors therefore concluded that an ordinary chondrite formed the most likely projectile. Suevite samples recovered from the outcrops around the Bosumtwi crater were analyzed for PGE compositions, but did not allow the unambiguous detection of a meteoritic component in the impactites (Dai et al. 2005). These authors also concluded that the elevated PGE concentrations were probably related to the gold mineralizations, which are known in the Ashanti region. If the impactites recovered from the Bosumtwi cores LB-07A and LB-08A yield a clear signal of a meteoritic contamination, the comparison of PGE elemental ratios should confirm and eventually further refine the ordinary chondrite origin of the projectile proposed by Koeberl et al. (2004).

\section{IMPACTITE SAMPLES FROM LB-07A AND LB-08A AND METHODOLOGY}

During the ICDP sampling session of January 2005, twelve samples were selected from core LB-08A and thirteen from core LB-07A. Based on macroscopic and thin section examinations, a further selection took place with the aim of finding melt-rich zones, which are most likely to contain meteoritic contamination. The locations of the 13 samples selected (8 from LB-07A and 5 from LB-08A) for PGE analyses are reported in the reference log of Fig. 1. A limited petrographic description of these samples is given in Table 1 (for a more detailed description see Deutsch et al. 2007; Ferrière et al. 2007a, 2007b; Karikari et al. 2007; Morrow 2007). A single sample from core LB-05B was also analyzed. This sample LB-05B-117A was taken at the point of contact between the lake sediment and the impactite. It is likely to represent the fallback material that landed on the impactite at the end of the cratering process. This fallback material is further described in the paper by Koeberl et al. (2007b). The Os and $\mathrm{Cr}$ isotopic signatures of the Ivory Coast tektites seem to indicate that the distal ejecta material was enriched in a meteoritic component. It is thus important to test if this is also the case for the fall back material.

The 14 samples were first ground by hand in a corundum mortar, and then finely powdered with a corundum ball mill. This procedure adds no detectable PGE impurities to the samples (Tagle 2004). The PGE and Au were analyzed using NiS fire assay combined with ICP-MS at the GFZ in Potsdam, according to the method described by Plessen and Erzinger (1998) and Tagle and Claeys (2005). The quantitation limits for the PGE and $\mathrm{Au}$ determinations are $0.098 \mathrm{ng} / \mathrm{g} \mathrm{Ru}$, $0.022 \mathrm{ng} / \mathrm{g}$ Rh, $0.194 \mathrm{ng} / \mathrm{g} \mathrm{Pd}, 0.055 \mathrm{ng} / \mathrm{g} \mathrm{Ir}, 0.067 \mathrm{ng} / \mathrm{g} \mathrm{Pt}$, and $0.13 \mathrm{ng} / \mathrm{g} \mathrm{Au}$. This fire assay method efficiently concentrates the PGE from a silicate sample. The method combines good analytical precision and low detection limit; it can thus reliably measure even a minor proportion of meteoritic contamination in impact-melt rock (down to $\sim 0.1 \mathrm{wt} \%$ ). The accuracy and reproducibility of the PGE 
Table 1. The depth and summary of the petrographic descriptions of the samples from LB-07A and LB-08A analyzed in this study (all depths are below present-day lake surface).

\begin{tabular}{|c|c|c|c|c|c|}
\hline Borehole & Code & $\begin{array}{l}\text { Absolute depth of top } \\
(\mathrm{m})\end{array}$ & $\begin{array}{l}\text { Absolute depth of bottom } \\
(\mathrm{m})\end{array}$ & $\begin{array}{l}\text { Thickness } \\
(\mathrm{m})\end{array}$ & Lithology \\
\hline LB-07A & $7-1-1-2-95$ & 335.38 & 335.41 & 0.03 & $\begin{array}{l}\text { Polymict lithic breccia, } \sim 40 \% \text { clastic light gray groundmass, }<10 \% \text { clasts } \\
0.5 \text { to } 2 \mathrm{~cm} \text {, no melt identified }\end{array}$ \\
\hline LB-07A & $7-9-7-1-28$ BB & 356.51 & 356.54 & 0.03 & Polymict lithic breccia, more clast-rich, melt is present but very rare \\
\hline LB-07A & $7-13-11-3-25 \mathrm{BR}$ & 371.35 & 371.38 & 0.03 & $\begin{array}{l}\text { Polymict lithic breccia, dark-colored groundmass, } 50 \% \text { clasts, rare melt } \\
\text { fragments }\end{array}$ \\
\hline LB-07A & $7-19-18-1-13$ ТВ & 389.59 & 389.62 & 0.03 & $\begin{array}{l}\text { Light-colored suevite with small }(0.5 \mathrm{~cm}) \text { melt and solid clasts floating in } \\
\text { a porous clastic groundmass }\end{array}$ \\
\hline LB-07A & $7-24-22-5-55 \mathrm{BB}$ & 404.45 & 404.48 & 0.03 & $\begin{array}{l}\text { Light-colored suevite with larger }(\mathrm{cm}) \text { melt and solid clasts, floating in a } \\
\text { porous clastic groundmass }\end{array}$ \\
\hline LB-07A & $7-25-24-1-50 \mathrm{~TB}$ & 408.49 & 408.52 & 0.03 & $\begin{array}{l}\text { Light-colored suevite with larger }(\mathrm{cm}) \text { melt and solid clasts, floating in a } \\
\text { porous clastic groundmass }\end{array}$ \\
\hline LB-07A & $7-27-25-3-60 \mathrm{TR}$ & 412.17 & 412.20 & 0.03 & $\begin{array}{l}\text { Somewhat darker suevite with cm-size melt and solid clasts forming }>60 \% \\
\text { of the rock }\end{array}$ \\
\hline LB-07A & $7-45-37-4-24 \mathrm{BR}$ & 468.88 & 468.91 & 0.03 & $\begin{array}{l}\text { Lithic breccia with few }(<10 \%) \text { light-colored clasts (shales) in a white } \\
\text { groundmass }\end{array}$ \\
\hline LB-08A & $8-1-1-1-0$ TB & 235.62 & 235.65 & 0.03 & $\begin{array}{l}\text { Polymict lithic breccia with large fragments representing } \sim 60 \% \text { of the } \\
\text { rock, in a dark-colored groundmass, no visible melt clasts }\end{array}$ \\
\hline LB-08A & $8-8-8-5-7$ BB & 258.74 & 258.77 & 0.03 & $\begin{array}{l}\text { Contact between polymict lithic breccia and suevite with a few melt clasts } \\
\text { in a porous matrix }\end{array}$ \\
\hline LB-08A & $8-54-55-2-102$ ТВ & 399.87 & 399.90 & 0.03 & Graywacke, light gray in color, fine-grained with small rounded fragments \\
\hline LB-08A & $8-66-68-2-15$ BB & 435.82 & 435.85 & 0.03 & Graywacke, light gray in color, fine-grained with small rounded fragments \\
\hline LB-08A & $8-68-70-3-5$ BB & 442.42 & 442.46 & 0.04 & $\begin{array}{l}\text { Graywacke, light green to gray in color, fine-grained with small rounded } \\
\text { fragments }\end{array}$ \\
\hline
\end{tabular}


measurements is routinely tested by recurring analyses of three certified reference materials: a diabase TDB-1 with low PGE, and two gabbros WGB-1 and WMG-1 with low and high PGE concentrations, respectively (Govindaraju 1994). Another advantage of the ICP-MS NiS fire assay method is that all PGE except Os can be determined at the same time. During sample treatment, $\mathrm{OsO}_{4}$ volatilizes, and could only be determined quantitatively by adding an isotope spike. Since $\mathrm{Rh}$ proves itself more diagnostic for distinguishing the type of projectile than Os (Tagle 2004), external calibration solutions, which allow measuring $\mathrm{Rh}$, were used instead of the isotope dilution required to detect Os. The heterogeneity of PGE in many samples is commonly caused by their tendency to form alloy nuggets (Hall and Pelchat 1994). This nugget effect can account for a significant variation of PGE concentrations between several aliquots of the same sample. Representative and reproductive analyses can be obtained by taking large amounts of homogenized samples (10-100 g) to average out this nugget effect (Hall and Bonham-Carter 1988; McDonald 1998; Ely and Neal 2002). The results of multiple analyses of the same sample of the impact melt from the Popigai crater, using aliquots of 2, 5, and $10 \mathrm{~g}$, revealed that with a lesser quantity, the values obtained by repetitive analyses are not reproducible (Tagle and Claeys 2005). Using $10 \mathrm{~g}$ in identical analytical conditions, the results of several analyses of the same sample differed by less than $10 \%$. Consequently, the minimal sample weight for fire assay was $10 \mathrm{~g}$.

The impactite samples were also analyzed for majorand trace-element concentrations. The measurements were carried out by X-ray fluorescence spectroscopy (XRF) on glass beads with a SIEMENS SRS 3000 instrument at the Museum of Natural History in Berlin. The glass beads were prepared using $0.6 \mathrm{~g}$ of dried sample powder $\left(105{ }^{\circ} \mathrm{C}\right.$ for $4 \mathrm{~h}$ ) and $3.6 \mathrm{~g}$ of di-lithiumtetraborate (BRA A10 Specflux). For measurement and data analyses, a modified GEOQUANT program (SIEMENS) based on international rock standards and internal standards was used. Detection limits are $1.0 \mathrm{wt} \%$ for $\mathrm{SiO}_{2}, 0.5 \mathrm{wt} \%$ for $\mathrm{Al}_{2} \mathrm{O}_{3}, 0.1 \mathrm{wt} \%$ for $\mathrm{SO}_{3}, 0.05 \mathrm{wt} \%$ for $\mathrm{Fe}_{2} \mathrm{O}_{3}, 0.01 \mathrm{wt} \%$ for $\mathrm{TiO}_{2}, \mathrm{MnO}, \mathrm{MgO}$, $\mathrm{CaO}, \mathrm{Na}_{2} \mathrm{O}, \mathrm{K}_{2} \mathrm{O}$, and $\mathrm{P}_{2} \mathrm{O}_{5}, 30$ ppm for $\mathrm{Ba}$, and 15 ppm for $\mathrm{Co}, \mathrm{Cr}, \mathrm{Ni}, \mathrm{Rb}, \mathrm{Sr}, \mathrm{V}$, and $\mathrm{Zr}$. The standard errors are $0.5 \mathrm{wt} \%$ for $\mathrm{SiO}_{2}, 0.1 \mathrm{wt} \%$ for $\mathrm{Al}_{2} \mathrm{O}_{3}$ and $\mathrm{SO}_{3}, 0.05 \mathrm{wt} \%$ for $\mathrm{Fe}_{2} \mathrm{O}_{3}, \mathrm{MgO}, \mathrm{CaO}, \mathrm{Na}_{2} \mathrm{O}$, and $\mathrm{K}_{2} \mathrm{O}, 0.01$ wt $\%$ for $\mathrm{TiO}_{2}$, $\mathrm{MnO}$, and $\mathrm{P}_{2} \mathrm{O}_{5}, 30 \mathrm{ppm}$ for $\mathrm{Ba}$, and $5 \mathrm{ppm}$ for $\mathrm{Co}, \mathrm{Cr}, \mathrm{Ni}$, Rb, Sr, V, and Zr (Schmitt et al. 2004).

\section{THE BOSUMTWI TARGET ROCK}

Koeberl and Reimold (2005) recently documented the lithology and stratigraphy around the Bosumtwi crater and produced a detailed geological map of the region. The Bosumtwi target rock consists of 2.1-2.2 Gyr Birimian Supergroup greenschist facies metasediments. Metasediments, graywackes, phyllites, shales, schist, and meta-tuff, together with metavolcanics (i.e., altered basalts) to the southeast of the crater form the dominant lithologies. To the east and south of the crater, quartzites and conglomerate from the Tarwaian Supergroup crop out. Locally, intrusive lithologies are encountered, such as weathered granite and granodiorites, dikes or sills of olivine pyroxenite, dolerite, and gabbros, as well as more granitic dikes. The granitic bodies and the dikes occurring north of the crater are associated with the more distal Pepiakese and Kumasi batholiths.

The whole Ashanti region is known for its gold mineralization, which is being exploited in several mines. In their study of the PGE signature of the suevite found outside the crater, Dai et al. (2005) analyzed for comparison of a selection of ores from the Ashanti and Tarkwa mines located some $35 \mathrm{~km}$ and $50 \mathrm{~km}$ from Bosumtwi, respectively. This mineralization is considered stratigraphically equivalent to the Bosumtwi target rocks. The objective was to evaluate if such gold mineralization had been incorporated in the impact breccias during the cratering event. Schists forming the country rock of the Ashanti mine mineralization and amphibolites were analyzed for major, trace, and PGE concentrations along with conglomerates from the Tarkwa mine (Table 6 of Dai et al. 2005). The PGE chondrite normalized pattern of these samples differs from that obtained on the suevite. Dai et al. (2005) concluded that lithologies equivalent to those of the Ashanti and Tarkwa mines were not part of the Bosumtwi target rock, and could not explain the elevated PGE concentrations identified in the suevites. They added that some other, currently unidentified, local mineralization at or near Bosumtwi was probably responsible for the measured PGE abundances.

\section{RESULTS AND DISCUSSIONS}

The major- and trace-element concentrations measured on the Bosumtwi impactites from the cores LB-07A and LB-08A are presented in Table 2a. These results are in good agreement with previously published data and confirm the limited variation of the impactite composition and its compatibility with the target rock (Koeberl et al. 1998; Dai et al. 2005; Koeberl and Reimold 2005). Table 2b gives the PGE concentration determined on the 13 samples from LB-07A and LB-08A as well as the single sample of fallback ejecta from LB-05B 117-A3. The results of Table 2 are fully compatible with the 11 PGE analyses carried out on core LB-07A by McDonald et al. (2007) (Table 1). The PGE concentrations also agree with the data obtained on suevite samples collected from the crater rim and surrounding areas (Dai et al. 2005). The agreement is particularly good with three suevite samples, also analyzed by NiS-ICP-MS (Table 3), confirming the ability and reproducibility of this method for the determination of PGEs in impact-melt rocks. The PGE concentrations obtained from the Bosumtwi suevite 
Table 2a. Major- and trace-element concentrations measured on the 13 impactite samples from cores LB-07A and LB-08A.

\begin{tabular}{|c|c|c|c|c|c|c|c|c|c|c|c|c|c|c|c|}
\hline \multirow[t]{2}{*}{ Impactites } & LB-07A & LB-07A & LB-07A & LB-07A & LB-07A & LB-07A & LB-07A & LB-07A & LB-08A & LB-08A & LB-08A & LB-08A & \multicolumn{3}{|l|}{ LB-08A } \\
\hline & $7-1-1-2$ & 7-9-7-1 & $7-13-11-3$ & $7-19-18-1$ & $7-24-22-5$ & $7-25-24-1$ & $7-27-25-3$ & $7-45-37-4$ & $8-1-1-1$ & $8-8-8-5$ & $8-55-55-2$ & $8-66-68-2$ & $8-68-70-3$ & & \\
\hline Depth (m) & 335.4 & 356.5 & 371.3 & 389.6 & 404.4 & 408.5 & 412.2 & 468.9 & 235.6 & 258.7 & 399.9 & 435.8 & 442.4 & Ave. & St. dev. \\
\hline \multicolumn{16}{|l|}{$\mathrm{wt} \%$} \\
\hline $\mathrm{SiO}_{2}$ & 58.90 & 61.60 & 61.20 & 62.30 & 61.40 & 63.20 & 61.20 & 66.90 & 54.90 & 64.60 & 69.70 & 64.10 & 64.40 & 62.65 & 3.6 \\
\hline $\mathrm{TiO}_{2}$ & 0.55 & 0.54 & 0.53 & 0.51 & 0.56 & 0.55 & 0.56 & 0.52 & 0.73 & 0.56 & 0.37 & 0.44 & 0.43 & 0.53 & 0.1 \\
\hline $\mathrm{Al}_{2} \mathrm{O}_{3}$ & 14.90 & 15.40 & 15.30 & 16.50 & 15.90 & 16.10 & 17.30 & 14.50 & 16.50 & 15.40 & 14.10 & 14.70 & 14.00 & 15.40 & 1.0 \\
\hline $\mathrm{Fe}_{2} \mathrm{O}_{3}{ }^{\mathrm{a}}$ & 6.22 & 6.01 & 6.43 & 5.43 & 6.37 & 5.90 & 5.76 & 4.74 & 6.75 & 5.93 & 4.19 & 4.70 & 4.84 & 5.64 & 0.8 \\
\hline $\mathrm{MnO}$ & 0.07 & 0.06 & 0.05 & 0.05 & 0.05 & 0.05 & 0.05 & 0.06 & 0.11 & 0.05 & 0.04 & 0.06 & 0.06 & 0.06 & 0.0 \\
\hline $\mathrm{MgO}$ & 4.44 & 3.59 & 4.84 & 2.09 & 3.44 & 2.41 & 2.33 & 1.65 & 3.46 & 2.29 & 1.60 & 1.79 & 1.78 & 2.75 & 1.1 \\
\hline $\mathrm{CaO}$ & 4.34 & 2.50 & 1.73 & 2.22 & 2.25 & 2.21 & 2.15 & 2.80 & 5.36 & 2.04 & 2.10 & 3.97 & 4.25 & 2.92 & 1.2 \\
\hline $\mathrm{Na}_{2} \mathrm{O}$ & 2.44 & 2.76 & 2.54 & 3.67 & 2.66 & 2.75 & 3.21 & 2.65 & 2.51 & 2.75 & 4.03 & 2.94 & 2.94 & 2.91 & 0.5 \\
\hline $\mathrm{K}_{2} \mathrm{O}$ & 1.43 & 1.82 & 1.82 & 2.11 & 2.02 & 2.16 & 2.38 & 1.88 & 2.08 & 1.98 & 1.10 & 2.12 & 1.83 & 1.90 & 0.3 \\
\hline $\mathrm{P}_{2} \mathrm{O}_{5}$ & 0.12 & 0.09 & 0.09 & 0.09 & 0.11 & 0.10 & 0.10 & 0.08 & 0.24 & 0.11 & 0.08 & 0.09 & 0.20 & 0.12 & 0.1 \\
\hline $\mathrm{SO}_{3}$ & 0.10 & 0.10 & 0.10 & 0.10 & 0.20 & 0.10 & 0.10 & $<0.10$ & $<0.10$ & 0.10 & $<0.10$ & $<0.10$ & 0.20 & 0.12 & 0.0 \\
\hline LOI & 6.40 & 5.20 & 5.10 & 4.30 & 4.60 & 4.20 & 4.40 & 3.80 & 7.20 & 3.90 & 2.10 & 4.80 & 4.80 & 4.68 & 1.2 \\
\hline Total & 99.91 & 99.67 & 99.73 & 99.37 & 99.56 & 99.73 & 99.54 & 99.58 & 99.84 & 99.71 & 99.41 & 99.71 & 99.73 & 99.65 & 0.2 \\
\hline \multicolumn{16}{|l|}{$\mu \mathrm{g} / \mathrm{g}$} \\
\hline V & 119 & 115 & 119 & 113 & 119 & 110 & 121 & 97 & 126 & 106 & 88 & 91 & 93 & 109 & 13 \\
\hline $\mathrm{Cr}$ & 154 & 126 & 194 & 94 & 147 & 92 & 91 & 75 & 96 & 93 & 63 & 83 & 79 & 107 & 38 \\
\hline Co & 23 & 17 & 24 & $<15$ & 25 & 15 & $<15$ & $<15$ & $<15$ & $<15$ & $<15$ & $<15$ & $<15$ & 21 & 4 \\
\hline $\mathrm{Ni}$ & 126 & 91 & 204 & 44 & 239 & 66 & 46 & 27 & 50 & 42 & $<15$ & 33 & 27 & 83 & 71 \\
\hline $\mathrm{Cu}$ & $<30$ & 34 & 49 & $<30$ & 59 & 36 & 34 & 33 & 35 & 33 & 41 & 32 & 30 & 38 & 9 \\
\hline $\mathrm{Zn}$ & 71 & 74 & 71 & 66 & 75 & 75 & 75 & 57 & 86 & 75 & 56 & 60 & 59 & 69 & 9 \\
\hline $\mathrm{Rb}$ & 55 & 68 & 74 & 70 & 76 & 83 & 86 & 78 & 75 & 76 & 39 & 71 & 63 & 70 & 12 \\
\hline $\mathrm{Sr}$ & 404 & 349 & 296 & 448 & 350 & 360 & 411 & 320 & 537 & 311 & 542 & 397 & 460 & 399 & 80 \\
\hline Y & 11 & $<10$ & 13 & 12 & 13 & 14 & 15 & 10 & 15 & 25 & $<10$ & 12 & 14 & 14 & 4 \\
\hline $\mathrm{Zr}$ & 91 & 86 & 102 & 152 & 109 & 120 & 154 & 108 & 139 & 128 & 130 & 119 & 128 & 120 & 21 \\
\hline $\mathrm{Nb}$ & $<10$ & $<10$ & $<10$ & $<10$ & $<10$ & $<10$ & $<10$ & $<10$ & $<10$ & $<10$ & $<10$ & $<10$ & $<10$ & & \\
\hline Мо & $<10$ & $<10$ & $<10$ & $<10$ & $<10$ & $<10$ & $<10$ & $<10$ & $<10$ & $<10$ & $<10$ & $<10$ & $<10$ & & \\
\hline $\mathrm{Ba}$ & 495 & 584 & 533 & 687 & 581 & 606 & 645 & 591 & 565 & 656 & 456 & 614 & 582 & 584 & 63 \\
\hline $\mathrm{Pb}$ & $<15$ & $<15$ & $<15$ & $<15$ & $<15$ & $<15$ & $<15$ & $<15$ & $<15$ & $<15$ & $<15$ & $<15$ & $<15$ & & \\
\hline $\mathrm{Ce}$ & 42 & 33 & $<30$ & $<30$ & 39 & 31 & 48 & $<30$ & 41 & $<30$ & $<30$ & $<30$ & $<30$ & 39 & 6 \\
\hline Th & $<10$ & $<10$ & $<10$ & $<10$ & $<10$ & $<10$ & $<10$ & $<10$ & $<10$ & $<10$ & $<10$ & $<10$ & $<10$ & & \\
\hline $\mathrm{U}$ & $<10$ & $<10$ & $<10$ & $<10$ & $<10$ & $<10$ & $<10$ & $<10$ & $<10$ & $<10$ & $<10$ & $<10$ & $<10$ & & \\
\hline
\end{tabular}

${ }^{\mathrm{a} A l l ~} \mathrm{Fe}$ as $\mathrm{Fe}_{2} \mathrm{O}$. 
Table 2b. PGE concentration of 13 impactite samples from cores LB-07A and LB-08A as well as fall back material from core LB-05B117-A3. The detection limits in $\mathrm{ng} / \mathrm{g}$ are: $\mathrm{Ir}=0.055, \mathrm{Ru}=0.098, \mathrm{Pt}=0.067, \mathrm{Rh}=0.022, \mathrm{Pd}=0.194, \mathrm{Au}=$ 0.13 , Os was not measured.

\begin{tabular}{|c|c|c|c|c|c|c|}
\hline $\begin{array}{l}\text { Depth } \\
\text { (m) }\end{array}$ & $\begin{array}{l}\mathrm{Ir} \\
(\mathrm{ng} / \mathrm{g})\end{array}$ & $\begin{array}{l}\mathrm{Ru} \\
(\mathrm{ng} / \mathrm{g})\end{array}$ & $\begin{array}{l}\mathrm{Pt} \\
(\mathrm{ng} / \mathrm{g})\end{array}$ & $\begin{array}{l}\mathrm{Rh} \\
(\mathrm{ng} / \mathrm{g})\end{array}$ & $\begin{array}{l}\mathrm{Pd} \\
(\mathrm{ng} / \mathrm{g})\end{array}$ & $\begin{array}{l}\mathrm{Au} \\
(\mathrm{ng} / \mathrm{g})\end{array}$ \\
\hline \multicolumn{7}{|l|}{ Core 7A } \\
\hline 335.4 & 0.27 & 0.37 & 1.92 & 0.16 & 1.70 & 0.70 \\
\hline 356.5 & 0.14 & 0.21 & 7.21 & 0.15 & 1.33 & 1.66 \\
\hline 371.3 & 0.33 & 0.27 & 2.28 & 0.21 & 3.46 & 1.31 \\
\hline 389.6 & 0.12 & $<0.1$ & 0.51 & 0.04 & 0.47 & 0.33 \\
\hline 404.4 & 0.42 & 0.80 & 5.73 & 0.35 & 5.00 & 3.20 \\
\hline 408.5 & 0.43 & 0.11 & 1.52 & 0.14 & 1.06 & 0.65 \\
\hline 412.2 & 0.64 & 0.76 & 4.87 & 0.24 & 1.43 & 1.42 \\
\hline 468.9 & 0.18 & 0.12 & 1.68 & 0.09 & 1.04 & 0.99 \\
\hline Ave. & 0.32 & 0.38 & 3.22 & 0.17 & 1.94 & 1.28 \\
\hline St. dev. & 0.18 & 0.29 & 2.39 & 0.10 & 1.52 & 0.89 \\
\hline \multicolumn{7}{|l|}{ Core 8A } \\
\hline 235.6 & 0.12 & $<0.1$ & 0.85 & 0.07 & 1.35 & 0.94 \\
\hline 258.7 & 0.18 & 0.14 & 1.20 & 0.08 & 1.36 & 0.67 \\
\hline 399.9 & 0.08 & $<0.1$ & 0.80 & 0.04 & 0.55 & 0.82 \\
\hline 435.8 & 0.16 & 0.28 & 2.02 & 0.13 & 1.99 & 1.79 \\
\hline 442.4 & 0.10 & 0.11 & 0.61 & 0.03 & 0.63 & 0.46 \\
\hline Ave. & 0.13 & 0.18 & 1.10 & 0.07 & 1.18 & 0.94 \\
\hline St. dev. & 0.04 & 0.09 & 0.56 & 0.04 & 0.60 & 0.51 \\
\hline Core $5 \mathrm{~B} 117-\mathrm{A} 3^{\mathrm{a}}$ & 0.37 & 1.56 & 1.32 & 0.18 & 1.75 & 5.74 \\
\hline
\end{tabular}

${ }^{\mathrm{a} O n e}$ single analysis.

Table 3. Comparison of the PGE data obtained on the crater impactites with the 3 NiS-ICP-MS analyses of Dai et al. (2005) from the suevite outside the crater.

\begin{tabular}{|c|c|c|c|c|c|c|}
\hline Cores & $\begin{array}{l}\mathrm{Ir} \\
(\mathrm{ng} / \mathrm{g})\end{array}$ & $\begin{array}{l}\mathrm{Ru} \\
(\mathrm{ng} / \mathrm{g})\end{array}$ & $\begin{array}{l}\mathrm{Pt} \\
(\mathrm{ng} / \mathrm{g})\end{array}$ & $\begin{array}{l}\mathrm{Rh} \\
(\mathrm{ng} / \mathrm{g})\end{array}$ & $\begin{array}{l}\mathrm{Pd} \\
(\mathrm{ng} / \mathrm{g})\end{array}$ & $\begin{array}{l}\mathrm{Au} \\
(\mathrm{ng} / \mathrm{g})\end{array}$ \\
\hline \multicolumn{7}{|l|}{$7 \mathrm{~A}$} \\
\hline Average 8 samples & 0.32 & 0.38 & 3.22 & 0.17 & 1.94 & 1.28 \\
\hline St. dev. & 0.18 & 0.29 & 2.39 & 0.10 & 1.52 & 0.89 \\
\hline \multicolumn{7}{|l|}{$8 \mathrm{~A}$} \\
\hline Average 5 samples & 0.13 & 0.18 & 1.10 & 0.07 & 1.18 & 0.94 \\
\hline St. dev. & 0.04 & 0.09 & 0.56 & 0.04 & 0.60 & 0.51 \\
\hline LB-05B 117 A3 & 0.37 & 1.56 & 1.32 & 0.18 & 1.75 & 5.74 \\
\hline LB30A (Dai et al. 2005) & 0.25 & 0.24 & 1.0 & 0.13 & 1.3 & 3.0 \\
\hline LB30B (Dai et al. 2005) & 0.43 & 0.34 & 1.6 & 0.15 & 1.6 & 2.5 \\
\hline LB41 (Dai et al. 2005) & 0.19 & 0.18 & 0.98 & 0.12 & 1.4 & 5.7 \\
\hline
\end{tabular}

and impact breccias are slightly elevated compared to crustal value (Wedepohl 1995; Peucker-Ehrenbrink and Jahn 2001).

The CI-chondrite-normalized PGE patterns of Bosumtwi samples are presented in Fig. 2. The patterns differ from the rather flat model expected for chondritic values but appear more similar to that of the average continental crust. This suggests that the PGE content of the Bosumtwi target lithologies probably contributed significantly to the PGE composition of the impactites. As shown by Dai et al. (2005), the indigenous PGE concentrations in a variety of target lithologies (schist, metasediment, graywacke, granite) are high compared to normal crustal values and overlap with the concentrations obtained on the impactites both outside and within the crater. The presence of an extraterrestrial component in the Bosumtwi impactite cannot be confirmed. The meteoritic signature, if present, is probably very low $(<0.1 \mathrm{wt} \%$ of nominal $\mathrm{CI})$ and/or concealed by the elevated PGE contribution from the target rocks.

Figure 3 compares the chondrite-normalized pattern of the average of Bosumtwi impactite from cores LB-07A and LB-08A with that measured on the sample of fallback ejecta at the base of the lake sediment in cores LB-07A and LB-08A. The fallback pattern is flatter and more similar to that expected for a chondritic contamination. It is possible that a 

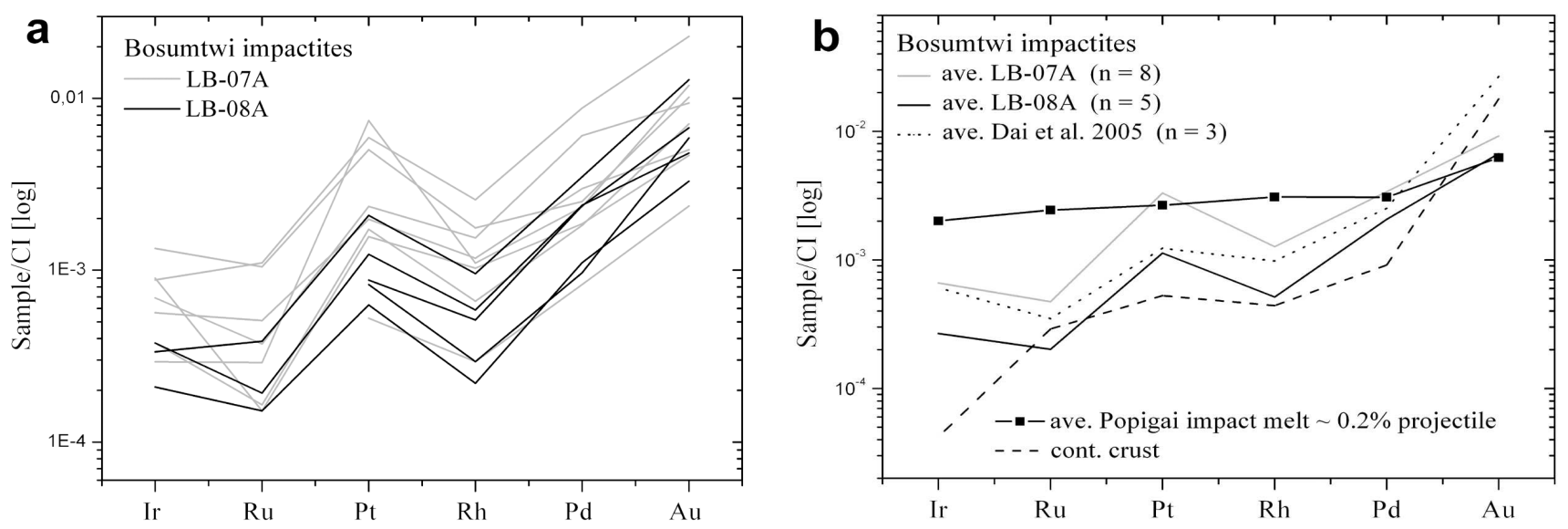

Fig. 2. a) CI-normalized PGE and Au concentrations of impactites from the Bosumtwi drill cores LB-07A and LB-08A. The PGEs are plotted from left to right in order of decreasing condensation temperature. b) CI-normalized PGE and Au concentrations (average values) of impactites from the Bosumtwi drill cores LB-07A and LB-08A, compared to average values of the three suevite samples originating from the crater rim (also NiS-ICP-MS analyses) (Dai et al. 2005). For comparison, the Popigai impact melt displays a rather flat chondritic pattern (Tagle and Claeys 2005). The composition of the average continental crust is shown for comparison. These values are based on the PGE concentrations of the eroding continental crust (loess) reported by Peucker-Ehrenbrink and Jahn (2001), except for the Rh data that were published in Wedepohl (1995) based on analyses of graywackes.

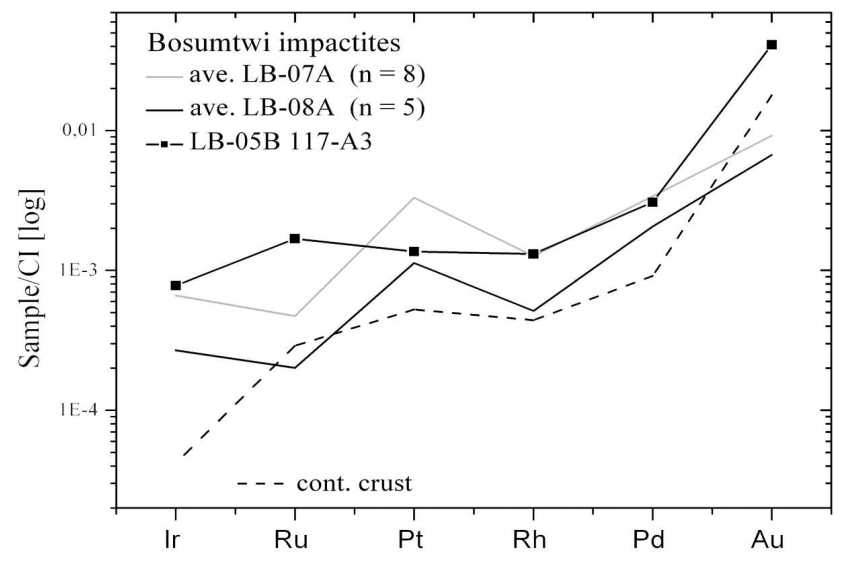

Fig. 3. Comparison of the PGE and Au patterns obtained for the Bosumtwi impactites of cores LB-07A and LB-08A with that of the single sample of fallback material in core LB-05B 117-A3.

meteoritic component is present in the fallback material. However, this would have to be confirmed by further analyses. Unfortunately, little amount of this fallback material was available for study, considering that the procedure used here requires $\sim 10 \mathrm{~g}$ of material.

The amount of meteorite material needed to discern the type of impacted meteorite depends on a variety of parameters: first of all, of course, the proportion of PGE in the projectile, but also the proportion of PGE in the target, the homogeneity of the impact-melt rock, and last but not least, the method applied to identify the extraterrestrial component. In homogenous and continuous impact-melt sheets, even in the case of a PGE-rich target, it is possible to distinguish minute $(\sim 0.2 \%)$ proportions of a chondritic projectile by using the regression method described by Tagle and Hecht
(2006). However, this regression method is not applicable to less homogenized impactites, as it is clearly the case here for Bosumtwi. When using CI-normalized element patterns for identification (Figs. 2 and 3), the minimal amount of projectile material required for identification actually depends on the PGE abundances in the target and on the original PGE concentrations of the projectile. Consequently, this method is much less sensitive as an elevated indigenous component in the target rock can disrupt the original projectile element pattern. Therefore, assuming a normal continental crust PGE pattern and using the Popigai ordinary chondrite impactor as a baseline (Fig. 3), the proportion of projectile in the Bosumtwi impactites of core LB-07A and LB-08A is significantly less than $0.1 \%$. At this level of contamination, the method used in this study is unable to discern the type of projectile. An interpretation of the possible projectile component of the sample $117 \mathrm{~A} 3$ is also problematic. The element pattern differs from the other samples, but again assuming a chondritic indigenous PGE concentration, the projectile component is below $0.1 \%$ of a CI-normative projectile with roughly $500 \mathrm{pbb}$ Ir.

\section{CONCLUSIONS}

The PGE concentration in 13 samples of impactites recovered from the Bosumtwi crater in Ghana provides no clear indication of a meteoritic origin. Based on the PGE elemental pattern obtained (Fig. 2), it seems that the target rock contribution dominates the PGE contribution in the impactites. These results agree with those of Dai et al. (2005) on suevites from the crater rim and with those of McDonald et al. (2007) on the impactites from LB-07A. However, it is possible that the one sample of fallback material extracted 
from lake sediment core LB-05B117-A3 contains a small meteoritic component (Fig. 3). This would agree with Koeberl et al. (2004), who reported, based on $\mathrm{Cr}$ and $\mathrm{Os}$ isotopic signatures, the presence of meteoritic material in the Bosumtwi ejecta, the Ivory Coast tektites. Based on their Os and $\mathrm{Cr}$ data, Koeberl et al. (2004) proposed that the projectile probably had a chondritic composition. We are hopeful that more fallback material will become available in the near future in order to confirm and eventually characterize the suspected meteoritic contamination.

The Bosumtwi case confirms that projectile identification in craters is not always a straightforward and easy task. It is possible to speculate on the causes of the lack of meteoritic signature in various craters. For some structures where a meteoritic contamination was not detected, e.g., Nördlinger Ries, Manicouagan, and Clearwater West, a differentiated achondrite projectile was proposed (e.g., Morgan et al. 1979; Wolf et al. 1980; Palme 1982). This kind of meteorite contains only low amounts of siderophile elements, which could explain the lack of contamination of the impactites. However, differentiated achondrites represent only around $2 \%$ of the total present meteoritic population. It could be argued that the present meteorite population perhaps differs in composition from the bodies that impacted Earth throughout geological time. Another potential line of reasoning is to advocate the impact of possible PGE-poor cometary bodies. Nevertheless, the absence of a PGE meteoritic component does not necessarily imply the absence of a PGE-rich projectile. This is best illustrated by the Chicxulub crater. Its impactites yielded no detectable meteoritic contamination (Gelinas et al. 2004; Tagle et al. 2004) despite that fact that worldwide the Cretaceous-Tertiary boundary ejecta layer is highly enriched in PGE (Alvarez et al. 1980). Most probably this is also the case for the Bosumtwi crater, where no clear PGE signature is found, but where ejecta (Koeberl and Shirey 1993; Koeberl et al. 2004), and possibly fallback material, contain a meteoritic component. Although fractionation, alteration, and/or postimpact mobilization can contribute to a modification of the meteoritic signature (e.g., McDonald et al. 2001; Evans et al. 1993; Colodner et al. 1992), these processes cannot account for the complete absence of a contamination. The percentage of meteoritic material that remains in the crater after the impact also depends on the impact velocity and angle of the impacting meteorites (Pierazzo and Melosh 2000). Artemieva et al. (2004) advocated an impact angle for Bosumtwi between 30 and $45^{\circ}$. Perhaps the composition of the target rocks, as well as the presence of volatile-rich layers could also play a role in the amount of projectile that is incorporated in the crater lithologies (Tagle 2004). Further research is needed to better understand the admixing of projectile during cratering events.

Acknowledgments-Drilling at Bosumtwi was supported by the International Scientific Continental Drilling Program
(ICDP), the U.S. NSF-Earth System History Program under grant no. ATM-0402010, Austrian FWF (project P17194N10), the Austrian Academy of Sciences, and by the Canadian NSERC. Drilling operations were performed by DOSECC. Local help by the Geological Survey Department (Accra) and KNUST (Kumasi), Ghana, was invaluable. R. Tagle thanks the Deutsche Akademie der Naturforscher Leopoldina for financial support (BMBF-LPD 9901/8-130); a grant from the "Onderzoeksraad" of the Vrije Universiteit Brussel to Ph. Claeys is also acknowledged. This work was part of Steven Goderis's master's thesis carried out at the departments of Geology at Ghent University and at the Vrije Universiteit Brussel. Reviews by Frank Kyte and Bernhard Peucker-Ehrenbrink together with the comments made by Christian Koeberl significantly improved the manuscript.

Editorial Handling-Dr. Christian Koeberl

\section{REFERENCES}

Alvarez L. W., Alvarez W., Asaro F., and Michel H. V. 1980. Extraterrestrial cause for the Cretaceous-Tertiary extinction. Science 208:1095-1108.

Artemieva N., Karp T., and Milkereit B. 2004. Investigating the Lake Bosumtwi impact structure: Insights from numerical modeling. Geochemistry Geophysics Geosystems 5:257-275.

Colodner D. C., Boyle E. A., Edmond J. M., and Thomson J. 1992. Post-depositional mobility of platinum, iridium, and rhenium in marine sediments. Nature 358:402-404.

Dai X., Boamah D., Koeberl C., Reimold W. U., Irvine G., and McDonald I. 2005. Bosumtwi impact structure, Ghana: Geochemistry of impactites and target rocks, and search for a meteoritic component. Meteoritics \& Planetary Science 40: 1493-1511.

Deutsch A., Luetke S., and Heinrich V. 2007. The ICDP Lake Bosumtwi impact crater scientific drilling project (Ghana): Core LB-08A litholog, related ejecta, and shock recovery experiments. Meteoritics \& Planetary Science 42. This issue.

Ely J. C. and Neal C. R. 2002. Method of data reduction and uncertainty estimation for platinum-group element data using inductively coupled plasma mass spectrometry. Geostandards Newsletter 26:31-39.

Evans N. J., Gregoire D. C., Grieve R. A. F., Goodfellow W. D., and Veizer J. 1993. Use of platinum-group elements for impactor identification-Terrestrial impact craters and Cretaceous-Tertiary boundary. Geochimica et Cosmochimica Acta 57:3737-3748.

Ferrière L., Koeberl C., and Reimold W. U. 2007a. Drill core LB08A, Bosumtwi impact structure, Ghana: Petrographic and shock metamorphic studies of material from the central uplift. Meteoritics \& Planetary Science 42. This issue.

Ferrière L., Koeberl C., Reimold W. U., and Mader D. 2007b. Drill core LB-08A, Bosumtwi impact structure, Ghana: Geochemistry of fallback breccia and basement samples from the central uplift. Meteoritics \& Planetary Science 42. This issue.

Gelinas A., Kring D. A., Zurcher L., Urrutia-Fucugauchi J., Morton O., and Walker R. J. 2004. Osmium isotope constraints on the proportion of bolide component in Chicxulub impact melt rocks. Meteoritics \& Planetary Science 39:1003-1008.

Govindaraju K. 1994. Compilation of working values and description for 383 geostandards. Geostandards Newsletter 18:1-154.

Hall G. E. M. and Bonham-Carter G. F. 1988. Review of methods to 
determine gold, platinum, and palladium in production-oriented geochemical laboratories, with application of a statistical procedure to test for bias. Journal of Geochemical Exploration 30:255-286.

Hall G. E. M. and Pelchat J. C. 1994. Analysis of geochemical materials for gold, platinum, and palladium at low ppb levels by fire assay-ICP mass spectrometry. Chemical Geology 115:61-72.

Jones W. B. 1985. Chemical analyses of Bosumtwi crater target rocks compared with the Ivory Coast tektites. Geochimica et Cosmochimica Acta 48:2569-2576.

Karikari F., Ferrière L., Koeberl C., Reimold W. U., and Mader D. 2007. Petrography, geochemistry, and alteration of country rocks from the Bosumtwi impact structure, Ghana. Meteoritics \& Planetary Science 42. This issue.

Karp T., Milkereit B., Janle P., Danuor S. K., Pohl J., Berckhemer H., and Scholz C. A. 2002. Seismic investigation of the Lake Bosumtwi impact crater: Preliminary results. Planetary and Space Science 50:735-743.

Koeberl C. 1998. Identification of meteoritic components in impactites. In Meteorites: Flux with time and impact effects, edited by Grady M. M., Hutchison R., McCall G. J., and Rothery D. A. Special Publication \#140. London: Geological Society. pp. 133-153.

Koeberl C. and Reimold W. U. 2005. Bosumtwi impact crater, Ghana (West Africa): An updated and revised geological map, with explanations. Jahrbuch der Geologischen Bundesanstalt, Wien (Yearbook of the Austrian Geological Survey) 145:31-70 (+1 map, 1:50,000).

Koeberl C. and Shirey S. B. 1993. Detection of meteoritic component in Ivory Coast tektites with rhenium-osmium isotopes. Science 261:595-598.

Koeberl C. and Shirey S. B. 1997. Re-Os isotope systematics as a diagnostic tool for the study of impact craters and distal ejecta. Palaeogeography, Palaeoclimatology, Palaeoecology 132:2546.

Koeberl C., Reimold W. U., Blum J. D., and Chamberlain C. P. 1998. Petrology and geochemistry of target rocks from the Bosumtwi impact structure, Ghana, and comparison with Ivory Coast tektites. Geochimica et Cosmochimica Acta 62:2179-2196.

Koeberl C., Peucker-Ehrenbrink B., Reimold W. U., Shukolyukov A., and Lugmair G. W. 2002. Comparison of Os and $\mathrm{Cr}$ isotopic methods for the detection of meteoritic components in impactites: Examples from the Morokweng and Vredefort impact structures, South Africa. In Catastrophic events and mass extinctions: Impacts and beyond, edited by Koeberl C. and MacLeod K. G. GSA Special Paper \#356. Boulder, Colorado: Geological Society of America. pp. 607-617.

Koeberl C., Shukolyukov A., and Lugmair G. W. 2004. An ordinary chondrite impactor composition for the Bosumtwi impact structure, Ghana, West Africa: Discussion of siderophile element contents and $\mathrm{Os}$ and $\mathrm{Cr}$ isotope data (abstract \#1256). 35th Lunar and Planetary Science Conference. CD-ROM.

Koeberl C., Milkereit B., Overpeck J. T., Scholz C. A., Amoako P. Y. O., Boamah D., Danuor S., Karp T., Kueck J., Hecky R. E., King J. W., and Peck J. A. 2007a. An international and multidisciplinary drilling project into a young complex impact structure: The 2004 ICDP Bosumtwi Crater Drilling ProjectAn overview. Meteoritics \& Planetary Science 42. This issue.

Koeberl C., Brandstätter F., Glass B. P., Hecht L., Mader D., and Reimold W. U. 2007b. Uppermost impact fallback layer in the Bosumtwi crater (Ghana): Mineralogy, geochemistry, and comparison with Ivory Coast tektites. Meteoritics \& Planetary Science 42. This issue.

McDonald I. 1998. The need for a common framework for collection and interpretation of data in platinum-group element geochemistry. Geostandards Newsletter 22:85-91.
McDonald I. 2002. Clearwater East structure: A re-interpretation of the projectile type using new platinum-group element data from meteorites. Meteoritics \& Planetary Science 37:459-464.

McDonald I., Andreoli M. A. G., Hart R. J., and Tredoux M. 2001. Platinum-group elements in the Morokweng impact structure, South Africa: Evidence for the impact of a large ordinary chondrite projectile at the Jurassic-Cretaceous boundary. Geochimica et Cosmochimica Acta 65:299-309.

McDonald I., Peucker-Ehrenbrink B., Coney L., Ferrière L., Reimold W. U., and Koeberl C. 2007. Search for a meteoritic component in drill cores from the Bosumtwi impact structure, Ghana: Platinum-group element contents and osmium isotopic characteristics. Meteoritics \& Planetary Science 42. This issue.

Morgan J. W., Jannsens M. J., Hertogen J., Gros J., and Takahoshi H. 1979. Ries impact crater, southern Germany: Search for meteoritic material. Geochimica et Cosmochimica Acta 43:803-815.

Morrow J. R. 2007. Shock-metamorphic petrography and microRaman spectroscopy of quartz in upper impactite interval, ICDP drill core LB-07A, Bosumtwi impact crater, Ghana. Meteoritics \& Planetary Science 42. This issue.

Palme H. 1982. Identification of projectiles of large terrestrial impact craters and some implications for the interpretation of Ir-rich Cretaceous/Tertiary boundary layers. GSA Special Paper \#190. Boulder, Colorado: Geological Society of America. pp. 223-233.

Palme H., Janssens M. J., Takahasi H., Anders E., and Hertogen J. 1978. Meteorite material at five large impact craters. Geochimica et Cosmochimica Acta 42:313-323.

Pesonen L. J., Koeberl C., and Hautaniemi H. 2003. Airborne geophysical survey of the Lake Bosumtwi meteorite impact structure (southern Ghana)-Geophysical maps with descriptions. Jahrbuch der Geologischen Bundesanstalt, Vienna (Yearbook of the Austrian Geological Survey) 143:581-604.

Peucker-Ehrenbrink B. and Jahn B. M. 2001. Rhenium-osmium isotope systematics and platinum group element concentrations: Loess and the upper continental crust. Geochemistry, Geophysics, Geosystems 2, doi:10.1029/2001GC000172.

Pierazzo E. and Melosh H. J. 2000. Melt production in oblique impacts. Icarus 145:252-261.

Plado J., Pesonen L. J., Koeberl C., and Elo S. 2000. The Bosumtwi meteorite impact structure, Ghana: A magnetic model. Meteoritics \& Planetary Science 35:723-732.

Plessen H.-G. and Erzinger J. 1998. Determination of the platinumgroup elements and gold in twenty rock reference material by inductively coupled plasma-mass spectrometry (ICP-MS) after pre-concentration by nickel fire assay. Geostandards Newsletter 22:187-194.

Schmitt R. T., Wittmann A., and Stöffler D. 2004. Geochemistry of drill core samples from Yaxcopoil-1, Chicxulub impact crater, Mexico. Meteoritics \& Planetary Science 39:979-1001.

Scholtz C. A., Karp T., Brooks K. M., Milkereit B., Amoako P. Y. A., and Arko J. A. 2002. Pronounced central uplift identified in the Lake Bosumtwi impact structure, Ghana, using multichannel seismic reflection data. Geology 30:939-942.

Shukolyukov A. and Lugmair G. W. 1998. Isotopic evidence for the Cretaceous-Tertiary impactor and its type. Science 282:927-929.

Shukolyukov A., Lugmair G. W., Koeberl C., and Reimold W. U. 1999. Chromium in the Morokweng impact melt: Isotopic evidence for extraterrestrial components and type of impactor (abstract). Meteoritics \& Planetary Science 34:A107-A108.

Tagle R. 2004. Platingrupenelemente in Meteoriten und Gesteinen irdischer Impaktkrater: Identifizierung der Einschlagskörper. Ph.D. thesis, Humboldt-Universität zu Berlin, Berlin, Germany.

Tagle R. and Claeys P. 2005. An ordinary chondrite impactor for the Popigai crater, Siberia. Geochimica et Cosmochimica Acta 69: 2877-2889.

Tagle R. and Hecht L. 2006. Geochemical identification of 
projectiles in impact rocks. Meteoritics \& Planetary Science 41: $1721-1735$.

Tagle R., Erzinger J., Hecht L., Schmitt R. T., Stöffler D., and Claeys P. 2004. Platinum group elements in impactites of the ICDP Chicxulub drill core Yaxcopoil-1: Are there traces of the projectile? Meteoritics \& Planetary Science 39:1009-1016.
Wedepohl K. H. 1995. The composition of the continental crust. Geochimica et Cosmochimica Acta 59:1217-1232.

Wolf R., Woodrow A. B., and Grieve R. A. F. 1980. Meteoritic material at four Canadian impact craters. Geochimica et Cosmochimica Acta 44:1015-1022. 